\title{
What Factors Keep Cash Alive in the European Union?
}

\author{
Yulia Titova $^{1} \cdot$ Delia Cornea $^{2} \cdot$ Sébastien Lemeunier $^{2}$
}

Accepted: 12 April 2021 / Published online: 31 May 2021

(c) Springer Science+Business Media, LLC, part of Springer Nature 2021

\begin{abstract}
This paper aims to analyze the determinants of cash usage in a selection of European Union (EU) countries over the 2003-2016 period, based on a set of technological, socioeconomic, and socio-cultural indicators and cost components. Our results reveal the existence of both common and region-specific determinants for the EU advanced and Central and Eastern European (CEE) countries. In both groups cash usage is determined by payment system characteristics. Additionally, in the EU advanced countries cash usage can also be explained by the level of economic development and income inequalities and proliferation of Internet. In contrast, cash usage in CEE countries is negatively associated with consumer confidence and is inversely related to the technological progress, expressed in terms of mobile users.
\end{abstract}

Keywords Cash usage · Payment instruments · European Union · CEE countries · Panel data

JEL Classifications C23 $\cdot$ E41 $\cdot$ E42

\section{Introduction}

Many observers, including economists, industry players and policymakers, have predicted the move to a cashless society and "the end of cash", propelled by the increased diffusion of technological innovations that facilitate the use of electronic payments. Counter to these expectations, the recent decade has witnessed the resilience of cash, with a marked upsurge in cash in circulation after 2007 on a worldwide scale (for instance, in non-dollarized OECD economies cash in circulation hiked from a previously-stable 5.5\% of GDP to 6.5\% in 2009; Jobst and Stix 2017). Such a trend has attracted the attention of policymakers and raised the issue of reasons behind persistent cash usage. In 2017-2018, economists from central banks

\section{Yulia Titova}

y.titova@ieseg.fr

1 IÉSEG School of Management, 1 Promenade de l'Arche, 92800 Puteaux, France

2 EBS Paris/INSEEC U. Research Center, 13 Rue Saint-Lambert, 75015 Paris, France 
of Italy, Germany, Netherlands, among others, pondered on the factors explaining demand for cash in the course of specialized conferences, such as the International Cash Conference or the European Banknote Conference. Their reports reveal that cash is not likely to fade out completely as it serves as a safety cushion in case of malfunctioning electronic payment systems (Scholten 2017). Also, in countries struck by financial crises in or prior to 2007/08 demand for cash increased due to higher uncertainty (Jobst and Stix 2017).

It is, therefore, not surprising that despite a discernible substitution between cash and payment cards, the share of transactions for which cash is used relative to other payment media persists and is still significant in most European countries. In this context, we investigate the determinants of cash usage for a selection of EU countries for the period 2003-2016. The question of cash usage is of major importance, since on the one hand, demand for means of payment must be satisfied, while on the other hand, benefits arising from the supply of payment means are allocated to specific institutions with various aims and resources. ${ }^{1}$ As a result, our study is particularly relevant for central banks, in accordance with their mission to supervise the supply of money. This interest is underscored by a significant number of reports on means of payment provided by policymakers. It might also be of interest to industry players from the supply chain of currency and payment systems, as gaining insights into the currency demand will provide them with a higher visibility on their future operations.

Since 2000, there has been a large body of literature explaining users' choice of different payment instruments for their transactions. Through different methods, the literature explains the substitution of cash holdings with alternative payment means. It studies preferences of consumers for the characteristics of these means of payment and then portrays the consumers' profiles. It also explains this allocation, thanks to incentives related to the price setting of payment cards and the availability of ATMs (Automated Teller Machines) and EFTPOS (Electronic Funds Transfers at Points of Sale). Most of these studies apply diary and survey approaches and focus on a single country (see, among others, Bounie et al. 2016; Klee 2008; Jonker et al. 2012; Bouhdaoui and Bounie 2012; von Kalckreuth et al. 2011; Borzekowski et al. 2008; Górka 2012; Jonker 2007; Végsö et al. 2018). More precisely, these studies find that users' preferences between cash and card payments may be explained by their income levels, their education levels, safety perceptions, and access to new technologies, among other factors. Besides effective payment patterns, the existing literature also sheds light on the difference between stated and actual means of payments used by consumers. Using diary survey data for the Netherlands, van der Cruijsen et al. (2017) explore the discrepancy between cash and debit card preferences and actual payment behaviour and conclude that payment habits are a major driver of the gap. Besides payment habits, other socio-psychological factors, such

\footnotetext{
1 The supply of money comes from a sovereign power that has most often been delegated to central banks. It is allocated according to various monetary policy tools, including the amount of cash in circulation. Central banks can share the provision of cash with private actors such as banks. We have chosen to study the expression of cash dynamics by users in this restricted supply framework.
} 
as attitudes, feelings, perceived control and social norms are also relevant in steering consumer choice of payment means (van der Cruijsen and van der Horst 2019). Recently, several studies integrated the results of country-specific diary surveys in order to check if there were universal factors determining cash usage. Thus, Bagnall et al. (2016) show that the use of cash is correlated with the transaction size, consumer preferences, demographics and POS characteristics. Arango et al. (2018) find that cash usage can primarily be explained by the relative cost of the means of payment. These studies confirm the previous findings based on single-country surveys, but on the other hand point out the importance of cross-country differences. If these elements of the literature are relevant in explaining the usage of cash at the individual level, we examine if this is still the case when we aggregate these dynamics at a country level.

Another major stream of the cash literature investigates the differences in the usage of cash based on macroenomic panel data models for advanced countries (Humphrey et al. 1996; Amromin and Chakravorti 2009; Drehmann et al. 2002; Snellman and Viren 2009). These studies focus mainly on the traditional determinants of cash demand, such as interest rate, GDP level and the technological diffusion of ATMs and EFTPOS, which changed the individuals' choices of different payment instruments in a significant way. In addition, Bech et al. (2018) analyse the impact of the increased uncertainty generated by the recent financial crisis.

Recent years have witnessed a renewed attention from researchers and policymakers to the factors explaining the choice of cash as a payment instrument (Arango-Arango and Suárez-Ariza 2019; Ashworth and Goodhart 2020). As mentioned above, this interest is fuelled, on one hand, by the importance of this topic for central banks as they make decisions about the supply of banknotes and coins; on the other hand, by the persistence of cash usage, despite recent technological innovations in payments and regulatory efforts to encourage the use of digital payment media. Our paper adds to the existing literature and provides several contributions. First, we perform a separate analysis for two groups of countries within the European Union: Central and Eastern European countries (CEE) and EU advanced countries. ${ }^{2}$ This allows us to control for intrinsic differences between these two subsamples. To explain cash usage, we consider several sets of country characteristic variables that fall into four main categories: technological factors, cost components, socioeconomic markers, and socio-cultural indicators. ${ }^{3}$ Second, most other papers analysing cash usage use cash in circulation as the dependent variable. Our

\footnotetext{
${ }^{2}$ EU advanced countries correspond to the EU-15 group. CEE countries or "CEECs" designs a group of Central and Eastern European countries. This definition is common and can be found in research papers (Shujah-ur-Rahman et al. 2019; Albulescu et al. 2019) and also in those published by institutions such as the ECB (Buelens and Tirpák 2017). The number of components in this group evolved in the past due to the enlargement of the EU. The list of CEE countries that are EU members comprises Bulgaria, Croatia, the Czech Republic, Hungary, Poland, Romania, the Slovak Republic, Slovenia, Estonia, Latvia and Lithuania. The distinction between EU advanced/CEE countries is not only a statistical term, but also a political one and is convenient to put into perspective two groups of countries with different habits.

3 Macroeconomic perspective was also applied in some studies focusing on determinants of non-cash payment instruments (see, for example, Guariglia and Loke (2004), Goczek and Witkowski (2016) and Silva et al. (2017)).
} 
paper distinguishes from these studies in that our methodology allows us to estimate domestic demand for cash. This enables applying a macroeconomic approach consistently and using country-level indicators. Third, we control for the potential endogeneity between cash usage and payment networks by estimating a two-stage least squares model.

The selected timeframe offers a particularly interesting research setting for CEE countries in transition, their economies being characterized by relatively high interest rates, strong inflationary pressures, and the use of the euro as a reserve currency. There is also scant evidence on the use of payment means for CEE countries. This study therefore brings new insight into demand for cash in this region. However, the nations comprising the European Union (EU) differ in the ways they adopt alternative media. If there is a convergence in the usage of payment instruments within the EU, it appears to be particularly slow when it comes to habits in cash usage (Martikainen et al. 2015). Consequently, we conduct a comparative analysis of two distinctive groups: EU advanced countries and Central and Eastern European countries (CEE).

In this light, we rely on the methodology used by Evans et al. (2013) to estimate cash usage. We conduct our analysis for a sample of 19 EU countries, splitting the full sample into two sub-samples reflecting advanced EU countries and CEE countries. We test two regression models based on an OLS and a two-stage LS model, both with country fixed effects. The second model accounts for endogeneity between our cash usage measure and variables characterizing the supply of available payment instruments.

The results reveal both common and diverging determinants of cash usage for the two groups of countries. A higher dynamics of the technological infrastructure allowing for card payments relative to ATMs is associated with a lower use of cash. These results hold for both EU advanced and CEE countries. Moreover, for CEE countries the level of education attainment still plays an important role in the consumer choice of payment instruments, reflecting a negative relationship with cash usage. However, the level of income reveals an opposite effect on cash usage for the groups of countries analyzed in our study: real GDP per inhabitant is negatively related to cash usage in EU advanced countries, but has a positive impact on CEE countries. An increase in income generates two distinctive effects: first, it boosts the consumption and increases the use of all payment instruments; on the other hand, it changes the payment behavior by substituting cash with electronic payments. The positive correlation of real GDP per capita with cash usage in CEE countries is an evidence that the consumption effect prevails. Technological factors reveal contrasting results, with Internet penetration positively correlated with the proliferation of cash in EU advanced countries. In CEE countries, cash usage is negatively correlated with technological progress measured by the number of mobile users, the indicator which showed an important dynamic over the estimation period. Also, for these countries a decrease in the consumer confidence is associated with a soaring usage of cash reflecting a perceived increase in uncertainty. Moreover, in CEE countries cash is more intensively used by people at the extremes of the age distribution. The usage of cash in EU advanced countries is inversely related to the level of income inequality. Contrary to our expectations, there is no robust evidence that 
cash usage is related to relative cost of cards compared to cash, corruption perception, cash payment limits or to the fraction of the self-employed.

Following this introduction, section 2 describes and motivates the choice of the three main groups of country characteristic variables. The third section discusses data and the methodology. Section 4 presents the results of our empirical models and section 5 concludes.

\section{Determinants of cash usage: theoretical background and assumptions}

This section justifies the potential determinants chosen to explain cash usage. We distinguish three groups of determinants extracted from the literature. Some of them are specifically mentioned in the relevant studies. For others, we use their aggregate equivalent as a projection of individual characteristics on the macroeconomic level, with proper arguments.

\subsection{Technological factors}

The evolution in the supply of payment instruments is related to technological progress. From this perspective, more technologically advanced countries are expected to rely more heavily on electronic payment instruments that integrate higher technology. Moreover, in the context of payment systems, technological endowment allows the existence of payment cards and their efficiency by developing networks of ATMs and EFTPOS. This framework arbitrates the users' choices of different payment instruments and their availability (see, among others, Alvarez and Lippi 2009; Lippi and Secchi 2009; Scholnick et al. 2008; Markose and Loke 2003; Attanasio et al. 2002). The increase in the number of POS that allow electronic payments works as an incentive for card payments. Therefore, we expect EFTPOS availability to have a negative impact on cash usage. However, previous literature stresses a scissor or mixed effect regarding the impact of ATMs on cash withdrawals. On one hand, ATM diffusion is supposed to decrease the amount of funds withdrawn in individual transactions. On the other hand, the increased availability of ATMs is expected to increase the frequency of withdrawals. Therefore, the overall impact on the total amount of cash withdrawals is uncertain (see Snellman et al. 2001; Snellman and Viren 2009 for empirical evidence). Considering this scissor effect, for a given ATM per capita and the corresponding frequency and average amount of withdrawals, we investigate whether there is an increase or a decrease in the total amount of cash usage.

\subsection{Socioeconomic indicators}

Survey-based studies have highlighted the importance of income in explaining users' choices of different payment media. In this sense, their findings show a higher propensity to use cash for individuals with low income (see, for instance, von Kalckreuth et al. 2011; Bagnall et al. 2016; Hernandez et al. 2017). To approach 
this question at a macroeconomic level, we use the corresponding aggregate indicators. Therefore, we expect countries characterized by lower levels of development to show a higher preference for using cash. Moreover, countries with higher income inequalities are likely to be characterized by a higher persistence in cash usage due to the fact that some citizens in the bottom segments of the income distribution may not have access to alternative payment media (Srouji 2020). Additionally, countries that were more negatively impacted by the financial crisis are likely to use more cash.

The interest rate is a traditional variable used to explain the demand for cash. According to the Baumol-Tobin model, holding cash bears an opportunity cost, and the demand for cash is negatively related to the interest rate. Humphrey et al. (1996) and Snellman and Viren (2009) empirically confirm this negative relationship between interest rate and cash usage. However, Amromin and Chakravorti (2009) and Bech et al. (2018) show that this relationship holds only for large denomination banknotes used mostly for the store-of-value motive. This implies that cash usage in our study should be negatively related to the level of interest rates. Nevertheless, during the period covered in our study, European Union countries experienced significant changes in interest rates, which declined after the outbreak of the 2007/08 financial crisis, dropping to virtually zero in the euro area. Consequently, we expect that this environment spurred the building up of cash holdings, as low interest rate levels subdue incentives to keep extra cash in deposit accounts.

\subsection{Socio-cultural indicators}

Previous studies explain that the users' behavior may be partly explained by their level of education (Klee 2008; von Kalckreuth et al. 2011; Bagnall et al. 2016). Their results reveal that individuals with low levels of education show a preference for cash as a payment instrument. Therefore, if we translate this at an aggregate level, we expect countries characterized by lower education levels to show a higher cash usage. Moreover, previous studies demonstrated that the propensity to pay with cards decreases with age, and older people are therefore more likely to use cash (Klee 2008; Jonker et al. 2012).

Another mainstream trend followed by survey studies is based on the characteristics of payment means. Cash may be desirable because it provides anonymity to its holder. This preference is partially motivated by underground activities reflected by the share of the shadow economy and the degree of corruption. According to these elements, a country with a high degree of perceived corruption is supposed to use cash more intensively. In a similar vein, some authors have also argued that cash demand can be buoyed by a higher proportion of self-employed. The rationale behind this claim is rooted in the belief that the related activity is conducted, at least partially, in the grey economy, as it might be easier for the self-employed to avoid or evade taxes (Goodhart and Ashworth 2014). Additionally, self-employed are more likely to be smaller merchants who tend to adopt new payment technologies more slowly due to higher costs that they incur (Amromin and Chakravorti 2009). On the contrary, one of the main disadvantages of using cash is its safety perception (Kosse 
2013; Kosse and Jansen 2013), as it is quite easy to steal from its holder. The risk of loss due to theft is considered one of the main costs of holding cash (Hazra 2017).

\section{Data and methodology}

\subsection{Data}

Our sample includes a selection of EU countries for the period 2003-2016. Our study combines several databases: the European Central Bank Statistical Data Warehouse, Eurostat, the World Bank World Development Indicators database and Transparency International. For more details, please refer to Table 6 in Appendix.

\subsection{Measuring cash usage}

To study the dynamics of cash usage, we are interested mainly in transaction and precautionary motives since fiat money no longer plays a role in the speculative motive as described by the traditional model for money demand. Nevertheless, measuring the exact value and volume of cash usage is prone to empirical difficulties, because cash transactions are unregistered; hence they are unobservable and untraceable. However, there are different methods that can be applied to measure cash usage (see Schmiedel et al. 2012 for a description of these methods). Our study implements the "cash withdrawal data" approach. According to this method, the value of cash payments can be estimated by summing up the cash amounts obtained through the following channels (Takala and Viren 2012): ATM withdrawals; OTC withdrawals (cash received directly from bank counters); cashback (cash received at selling points); and cash recycling (cash transfers between individuals). We measure cash usage as the sum of ATM withdrawals and OTC withdrawals, which is consistent with Evans et al. (2013). In value terms, these two channels represent the majority of cash sources for consumers in all analyzed countries. We remove cashback from the calculation, because this option is present in just a few countries and is likely to have a very limited impact on the estimation of cash usage. To get the most reliable estimations of cash usage, cash recycling should be controlled for. These transfers of cash between individuals-for example, within a family_are referred to as public recycling and represent the secondary spending of cash received from other sources, such as deposit accounts (Takala and Viren 2012). The data on public recycling are not available; however, estimates exist based on the recycling rates revealed from occasional surveys. While they are available for the eurozone countries, estimates are missing for other EU countries. Moreover, according to Takala and Viren (2012)'s approximations, public recycling is likely to be limited and capped at $15 \%$ of the total primary cash distribution. In order to ensure the consistency of estimates and comparability of countries across the sample, we therefore exclude cash recycling from our cash usage measure on the grounds of non-observability of recycling rates. The method based on cash flows adopted in our paper focuses on domestic demand for cash based on the demand for transactional 
motive, but also domestic hoarding (Evans et al. 2013; Takala and Viren 2012), which allows us to use country-specific factors for the EU countries. However, we cannot disentangle transactional and domestic hoarding motives, as large-denomination banknotes in circulation can be used for both domestic hoarding and external demand (Bartzsch et al. 2013; Lalouette and Esselink 2018; Bech et al. 2018).

The data on ATM withdrawals are collected by the European Central Bank (ECB) and are available for all the countries in the European Union, except for Denmark and Croatia which report these data only starting from 2013. The amounts of OTC distribution of cash are also provided by the ECB, but are missing for several countries in our sample, and therefore need to be inferred from countries with available data. Countries such as Austria, Denmark, Luxembourg, Poland and Sweden have no reported data for OTC withdrawals in the ECB Statistical Data Warehouse, whereas Belgium, Bulgaria, Czech Republic, Germany, Estonia, Ireland, Lithuania and Slovenia report OTC withdrawals only for a part of our analyzed period. ${ }^{4}$ We have decided to keep in our analysis only countries with full or partial disclosure of OTC withdrawals to reduce the estimation error. To estimate the OTC withdrawals for the countries for which these withdrawals are not disclosed, we rely on the approach proposed by Evans et al. (2013). They grouped countries into several categories based on variables such as the number of ATMs/inhabitant, ATM withdrawals/GDP, number of branches/inhabitant, and they made the assumption that countries from the same group have the same OTC/ATM ratio (considering that this ratio follows a logarithmic trend). Therefore, they inferred the value of the OTC/ATM withdrawals ratio and the missing OTC withdrawals. Following this methodology, we group countries in our sample that share similar withdrawals patterns. For this purpose, we identify five indicators that might explain the consumers' choice of ATM or OTC withdrawals: the number of ATM terminals per 1,000 inhabitants (expressed as the average value and the cumulative average growth rate for the period), the number of bank branches per inhabitant (expressed as the average value and the cumulative average growth rate for the period), the percentage of population with an account, the percentage of population with a debit card and the percentage of population with a credit card. The data for ATM withdrawals and bank branches are provided by the ECB Statistical Data Warehouse. Other indicators are sourced from the World Bank Global Financial Inclusion database. To create the groups, we have opted for a hierarchical clustering approach using the Ward option. ${ }^{5}$

The results of the cluster analysis are presented in Figure 1 and Table 1. Within each cluster, the data on OTC withdrawals are available for at least one country (when more than one country reports the OTC withdrawals we consider the average value). What differentiates our approach from Evans et al. (2013) is the assumption

\footnotetext{
${ }^{4}$ We consider Greece and Cyprus as outliers for the analyzed period due to the abnormal values of OTC to ATM ratios. For Malta, the number of EFTPOS is missing for several years.

5 A similar clustering approach was used by Schmiedel et al. (2012), who analyzed the characteristics of payment systems of EU-27 countries for the year 2009. They used a more comprehensive set of variables, including GDP per capita and their estimations of the social cost of payment instruments. However, as our approach consists in identifying cash usage regardless of economic and social development, countries were grouped based exclusively on variables characterizing the payment market.
} 
Table 1 Cluster composition

\begin{tabular}{lllll}
\hline Cluster 1 & Cluster 2 & Cluster 3 & Cluster 4 & Cluster 5 \\
\hline Belgium & Estonia & Finland & Bulgaria & Czech Republic \\
France & Latvia & Germany & Romania & Hungary \\
Italy & Netherlands & Ireland & & Lithuania \\
Portugal & & Slovenia & & Slovakia \\
Spain & & UK & & \\
\hline
\end{tabular}

This table presents the results of clustering based on five indicators: the number of ATM terminals per 1,000 inhabitants (expressed as the average value and the cumulative average growth rate for the period), the number of bank branches per inhabitant (expressed as the average value and the cumulative average growth rate for the period), the percentage of population with an account, the percentage of population with a debit card and the percentage of population with a credit card

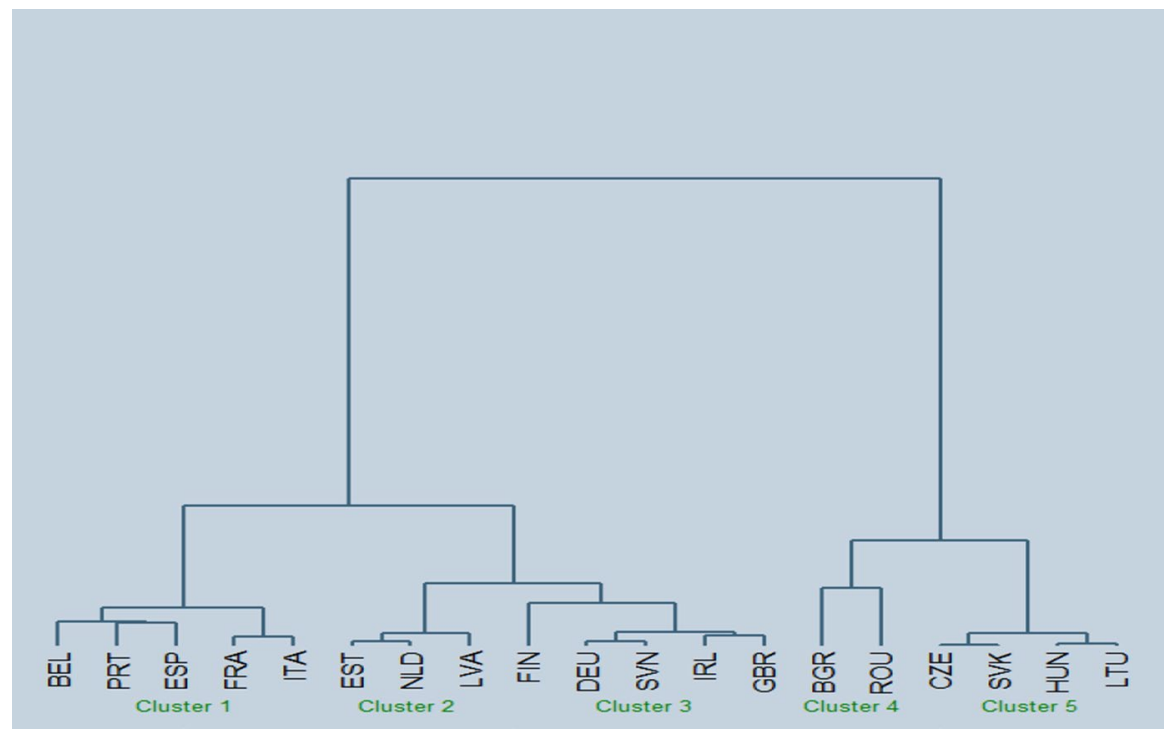

Fig. 1 Dendrogram for cluster analysis

that countries from the same cluster follow similar trends in the dynamics of the OTC/ATM ratio (but not the level of this ratio). Therefore, for each cluster we calculate the percentage change in the OTC/ATM ratio and we estimate an order three polynomial trendline. We then apply the estimated coefficients to calculate the OTC/ ATM ratio for each country in the corresponding cluster for which the OTC data are not available. The product of the estimated ratio and disclosed ATM withdrawals is used as a proxy for OTC withdrawals. 


\subsection{Empirical specification}

We have estimated the following model:

$$
\begin{aligned}
\text { CASH }_{i, t}= & \alpha_{i}+\operatorname{TECHNO}_{i, t} \cdot \beta_{1}+\operatorname{COST}_{i, t} \cdot \beta_{2} \\
& +\operatorname{SOCIOECO}_{i, t} \cdot \beta_{3}+\operatorname{SOCIOCULTURAL~}_{i, t} \cdot \beta_{4}+\varepsilon_{i, t}
\end{aligned}
$$

Our dependent variable is the natural logarithm of the value of real cash usage per capita. According to our assumptions in the previous section, we identify four main categories of potential determinants of the dynamics of cash usage. $T E C H N O_{i, t}$ is a vector of technological indicators; $C O S T_{i, t}$ is a vector of relative cost of card payments compared to cash payments; $S O C I O E C O_{i, t}$ is a vector of socioeconomic variables; SOCIOCULTURA $L_{i, t}$ is a vector of socio-cultural indicators.

Technological factors include variables characterizing the availability of payment instruments such as the number of ATMs per inhabitant and the number of EFTPOS terminals per inhabitant. These two variables have been extensively used in previous research (see previous section). In our empirical specification we use ATM/ POS ratio because the relationship between cash usage and the number of ATMs may be driven by the relative dynamics of ATMs and EFTPOS, and this ratio allows capturing this effect. Moreover, we refrain from using the number of ATMs as an individual regressor, as this variable was applied in the cluster analysis and may thus result in a positive bias. As card payments are often associated with higher technology levels facilitating cash substitution, technological indicators such as Internet penetration rate and mobile subscription ratio are added to our model.

The relative cost of card payments versus cash payments is estimated using two components: Relative opportunity time cost and Relative safety perceptions. Previous studies (Carbo-Valverde and Rodriguez-Fernandez 2019; Danmarks Nationalbank, 2012; Turján et al. 2011) identified three main components of cash and payment cards costs. The first component is based on transaction costs and reflects the opportunity time cost of getting and paying with different media. The second component reflects the security aspects based on measures of safety perception. The third component is based on fees and other charges paid by payment media users (e.g. annual fees for cardholders, ATM withdrawal fees, surcharges applied by retailers). We disregard the measure based on fees and other charges due to the scarcity of data that will not allow us to extrapolate the results to our dataset. Therefore, the first component considers the opportunity time cost of getting in the position of the payment instrument and the relative cost of transaction processing time from the consumers' point of view. In this setting, we estimate the transaction cost per ATM withdrawal following (Segendorf and Jansson 2012 and Krüger and Seitz 2014) based on inventory model approach (the opportunity cost of withdrawals is calculated based on average withdrawal value and the nominal interest rate). The time processing cost was calculated based on estimates provided by previous studies. We have identified 10 studies that provided specifically this information for EU countries based on similar methodologies (Polasik et al. 2010; Cabinakova et al. 2017; Banque Nationale de Belgique 2005; Brits and Winder (2005); Jonker (2013); Turján et al. (2011); Danmarks Nationalbank 2012; Abele and Schaefer (2016); Schmiedel 
et al. (2012); Segendorf and Jansson (2012)) as the time processing cost enters in the calculation of both internal costs for consumers and retailers. The results of the above mentioned studies show that cash has an advantage in terms of transaction processing time relative to payment cards; however, the difference between these two instruments is decreasing over time due to technology improvements (Jonker 2013; Polasik et al. 2010). We extrapolate the missing data using the clustering approach provided by Schmiedel et al. (2012) that grouped the EU countries based on cost measures and other payment market variables. Moreover, we estimated the dynamics in payment processing time based on the findings of Jonker (2013). We, therefore, estimated the additional cost of paying with cards as an opportunity cost of transaction processing time (transaction processing time multiplied by real net earnings). The final cost measure is the ratio between the additional cost of payment processing for cards and the opportunity cost of withdrawals.

Relative safety perceptions are represented by the ratio of a proxy for safety perceptions of cards to a proxy of safety perceptions of cash. We use card fraud rates as a measure of safety perceptions of card payments. Fraud rates for all countries in our sample are provided by the ECB for the period starting from 2010, as a result of the harmonized implementation of the oversight framework for card payment schemes. To extrapolate the missing data for the 2003-2009 period, we applied the following methodology. Euromonitor International provides data on value lost in fraud for payment cards for selected countries from our sample (Czech Republic, France, Germany, Hungary, Italy, Netherlands, Portugal, Romania, Spain, UK) for the period starting from 2005. We have estimated corresponding fraud rates by dividing value lost to fraud by value of card payments obtained from the ECB Statistical Data Warehouse. We then calculated annual change rates, which we then applied to fraud rates provided by the ECB. For countries, where the data were not available in Euromonitor, annual change rates were estimated using the clustering approach provided by Schmiedel et al. (2012). Finally, fraud rates for 2003 and 2004 were extrapolated using the most appropriate trend for a given country. To reflect the safety perception of using cash, we use robbery rate. Previous studies (see, for instance, Humphrey et al. 1996) used violent crime. Robbery is a subset of violent crime which is more directly linked to money-related issues and is therefore a better proxy for safety perceptions.

Within the socioeconomic category, we include variables such as real GDP per capita, expressed in the natural logarithm form, and Gini index as proxies in examining the relationship between the level and inequality of income, respectively, and cash usage. To account for the level of uncertainty in a country we add a set of variables linked to the financial crisis or the economic context in general: a crisis 2008-2009 dummy, a crisis 2011-2012 dummy and the consumer confidence indicator. The crisis periods correspond to the market shocks induced by the financial crisis and the European sovereign debt crisis and are in accordance with Ashworth and Goodhart (2020). In addition, we introduce a dummy variable for a negative interest rate, equal to one if the real interest rate is negative and zero otherwise. The rationale for using this variable is twofold. First, nominal interest rates in the EU have declined sharply after the 2007/09 financial crisis, with the ECB deposit facility rate falling below the zero level boundary in 2014. Although commercial banks are still 
reluctant to pass negative interest rates on customers, we may wonder if households and companies change their demand for cash as interest rates approach zero levels (Ashworth and Goodhart 2020). Second, CEE countries were characterized by high and volatile inflation rates during the study period, hence a variable based on the real interest rate may be a better proxy for the perception of uncertainty.

The socio-cultural factors category includes the education rate, age dependency ratio ${ }^{6}$ share of self-employed and corruption perception index.

Cash usage may also be related to various legal restrictions imposed on cash. For example, in France the maximum amount of cash payment is set at 1000 euros, while in Germany or Slovenia there are no limits. Therefore, to control for these boundaries, we introduce the Cash limits variable, which is equal to 0 for those countries which do not impose any limits on payments made in cash, and one divided by the natural logarithm of cash limits expressed in euros.

Table 6 in the Appendix provides a detailed description of these indicators, along with the sources.

Table 2 displays the list of countries used in our analysis. Table 3 presents descriptive statistics for the variables used in our analysis, along with a supplementary classification between EU advanced countries and CEE countries. EU advanced countries are characterized by higher GDP per capita and a lower relative endowment of ATMs. They also present a greater penetration of Internet (see Panel A and $\mathrm{B}$ of Table 3). Moreover, the estimated real cash usage per capita is slightly higher for EU advanced countries than for CEE countries, albeit with a higher standard deviation. It may be inferred that EU advanced countries are more heterogeneous than CEE countries. This result is in line with previous studies that emphasized important changes in the payment habits of individuals in these countries and the fact that despite their economic and technological development, some EU advanced countries are still cash-intensive. Therefore, considering the important differences in economic, socio-cultural and technological developments that can generate different patterns in the usage of payment instruments, the determinants of cash usage will be analyzed for these two sub-samples.

However, the model described above may suffer from endogeneity issues. Previous literature has documented how the relationship between the usage of different payment instruments and various characteristics of payment systems, such as the diffusion of ATMs and the proliferation of EFTPOS terminals, as well as some cost components, can be characterized by reverse causality. Indeed, the causality between cash usage and the characteristics of the payment system is unclear, because higher usage of cash due to entrenched habits may lead to an increase in the number of ATMs and a decline in the number of EFTPOS terminals. This may result in a non-zero correlation between the standard error of the dependent variable and an independent variable, in which case ordinary least squares (OLS) yield biased and inconsistent results. To overcome this problem, endogenous variables are corrected based on instrumental variables. Therefore, we apply a two-stage least squares

\footnotetext{
${ }^{6}$ We use age dependency ratio to account for the concentration of cash payments at both extremes of the age distribution as highlighted by Végsö et al. (2018).
} 
(2SLS) model with instrumental variables for ATM/POS ratio and relative opportunity time cost component. As instrumental variables, we use the following set of instruments (depending on the specification): the growth rate in the number of cards with a payment function, the fixed telephone subscriptions per 100 people (as suggested by Arango-Arango and Suárez-Ariza (2019)), lagged ATM/POS ratio. Moreover, we introduced a supplementary instrument based on the total employment over population, which is in line with Lippi and Secchi (2009). The estimation was done in accordance with Schaffer (2010). We have estimated both OLS and 2SLS models with country fixed effects and using clustered-robust standard errors as suggested by Cameron and Miller (2015) and Petersen (2009). The same approach was used by Amromin and Chakravorti (2009) in a similar framework of estimating a currency demand. Recent studies (Arango et al. 2018; Schmiedel et al. 2012; Bagnall et al. 2016) show that payment habits are country specific, and that countries with comparable levels of development display different patterns in their choice of payment instrument (see Humphrey 2010 for a detailed analysis of factors that explain differences in payment markets across countries). By including country fixed effects, we limit omitted variable bias and control for time-invariant cultural factors.

\section{Results}

We describe our results by highlighting common and region-specific determinants of cash usage in the EU among technological factors, cost components, socioeconomic indicators, and socio-cultural indicators.

The results for the OLS model and the two-stage LS model are presented in Table 4 for CEE countries and in Table 5 for EU advanced countries. Equations (1) and (3) from the tables present the results of the model including all categories of factors. Considering that cost components can be influenced by the dynamic of technology endowments and changes in the interest rates. Equations (2) and (4) test a reduced form of the previous model. Therefore, we check if the results of the full model for the cost components are robust when not controlling for technological and interest rate related variables. The endogeneity test indicates that the ATM/POS and cost variables should be considered as endogeneous, therefore the two-stage LS model is more appropriate. We therefore restrain the discussion of the results to the estimations obtained via the instrumental variable approach.

\subsection{Common factors}

Our findings highlight that payment system characteristics determine cash usage in both $\mathrm{CEE}$ and EU advanced countries. The positive relationship between cash usage and the ATM/POS ratio corroborates theoretical predictions and the majority of previous findings. If the growth rate in the number of ATM terminals is more sluggish compared to that of the number of EFTPOS terminals, this results in a lower cash usage. A higher diffusion of ATMs is associated with a higher use of cash, as shown by Snellman and Viren (2009). Likewise, it is in line with the conclusions of Scholnick et al. (2008), who argued the existence of a substitution between ATM 
and EFTPOS transactions. Conversely, the acceptance of payment cards at points of sale facilitates the substitution of cash payments with card payments.

As demonstrated in previous studies, more highly-educated individuals have a greater propensity to keep up with technological progress and therefore to use electronic payment instruments. Therefore, education is negatively correlated with the usage of cash for both categories of countries. The results are in line with the findings of recent survey studies carried out in both CEE and EU advanced countries (see Ilyés and Varga 2015; Goczek and Witkowski 2016; Esselink and Hernández 2017; Świecka and Grima 2019; Végsö et al. 2018). However, these findings should be interpreted with caution, as the results for the EU advanced countries are not robust in the partial model.

\subsection{Region-specific factors: CEE countries}

For the CEE countries, real GDP presents a positive and robust impact on the extent of using cash. This could be explained by the payment habits of individuals from these countries. Ilyés and Varga (2015) show, in the context of Hungarian households, that cash payments continue to increase in line with income, despite the fact that the level of income increases the use of electronic payment instruments. Therefore, regardless of a change in payment habits at the point of sale where cash is gradually substituted by card payments, cash was still used extensively for transaction purposes. Esselink and Hernández (2017) concluded that cash-intensive countries use cash extensively, rather than remote payment instruments.

As expected, for the CEE countries a decrease in the consumer confidence is associated with a soaring usage of cash. In the context characterized by shattered confidence, including that in the banking system, along with high uncertainty, there is an allocation towards cash at the expense of payment cards. During market shocks defined in our study as the periods of financial crisis (2008-2009) and European sovereign debt crisis (2011-2012) the average consumer confidence was significantly lower than during the remaining periods. Hence, our results corroborate the findings of Seitz and Krueger (2017) and Jobst and Stix (2017), who explained a part of the increase in cash demand by greater uncertainty in the economy during the crisis.

The effect of cash substitution by alternative payment instruments seems to be reflected by the increased number of mobile users as a measure of technological progress. We test separately mobile and Internet penetration variables as both are measures of technological progress that facilitates electronic payments and creates the climate for the change in the consumer behavior. As Internet penetration is not statistically significant, we report the results for the mobile users variable.

We find a positive relationship between age dependency and cash usage, in line with Végsö et al. (2018). This variable is only marginally significant $(p$-value $=0.103)$ in Equation 4 from Table 4. 


\subsection{Region-specific factors: EU advanced countries}

For EU advanced countries, real GDP reveals a negative impact on cash usage, therefore a high economic development level fosters cash substitution as individuals migrate through electronic payment instruments. Furthermore, for these countries, higher income inequalities generate a lower usage of cash, as the Gini coefficient demonstrates a robust negative impact. Countries with a higher Gini coefficient may redistribute a lower proportion of the income or/and have a higher trend of "skillbiased technological change" (Dachs 2018). In both cases people with low wages do not benefit from higher income and do not increase their typical demand for cash for transaction motives.

Contrary to our expectations, Internet penetration is positively related to cash usage, but this relationship holds only for EU advanced countries. We also tested an alternative measure for technological development, number of mobile users, but the results show no statistical significance (results not reported). This finding may be justified for the considered period, which is characterized by a low confidence in secured payment on the Internet and by the fact that consumers were not as attached to electronic payment habits as they currently are. In addition to this, the Internet has allowed the implementation of platforms that interconnect people to exchange goods and services that would otherwise be excluded from traditional commercial networks. Moreover, these exchanges are mainly operated in cash, e.g. www.leboncoin.fr in France. Besides, Internet penetration allowed the flourishing of e-commerce, that boosted consumption and, in parallel, cash usage through "cash on delivery" payment option.

Cash usage increased during the 2008-2009 financial crisis. This is in line with the indings of Seitz and Krueger (2017) and Jobst and Stix (2017).

\subsection{Insights into the regional differences}

We also observe the opposite effect of GDP on cash usage across the CEE and EU advanced countries. Esselink and Hernández (2017) show that CEE countries that are part of the euro area are more prone to using cash for recurring expenses (such as rents, utility bills, medical payments) relative to EU advanced countries. These expenses represent an important share of the total consumption of households, and explains in part the reliance of these countries on cash. An increase in GDP can generate both a consumption and substitution effect. On the one hand, this will enhance the consumption and, therefore, a simultaneous increase in the use of all payment instruments. On the other hand, increases in the economic activity will induce the consumers to switch to electronic payments (this negative relationship is in line with Bech et al. 2018). The coefficient of GDP variable for CEE countries shows that a $1 \%$ increase in GDP will generate an increase of $1.5 \%$ in the cash usage (Equation 4) that increases to $2.2 \%$ when technological factors are taken into consideration. The positive sign of the GDP coefficient indicates a consumption effect that overcomes the substitution one. For EU advanced countries, real GDP variable negatively correlates with the extent of cash usage, indicating a substitution effect that prevails. 
These findings are in line with previous evidence that shows an important change in the payment behavior in most of these countries. Moreover, the income elasticity stays constant at $-2.3 \%$ when controlling for technological factors.

As far as the consumer confidence is concerned, we report a negative effect on cash usage in the CEE countries. On the contrary, we find a positive, but marginally statistically significant, relationship between cash usage and consumer confidence for the EU advanced countries. During periods of market turbulence, even if cash usage for precautionary motives is enhanced, the substitution generated by the transactional motive seems to offset this effect. Bech et al. (2018) found no robust effect between the demand for cash and the level of uncertainty. Moreover, for the EU advanced countries the impact of the lower consumer confidence could be partially offset by measures undertaken to shift the preferences of consumers from paper-based payment instruments to payment card usage. In that sense, Jonker et al. (2017) found that a public campaign carried out in 2007 in the Netherlands, aimed to encourage the use of debit cards, had a positive impact on consumers' and retailers' perception regarding this payment instrument.

We observe that cash usage is negatively related to the fraction of mobile users in the CEE countries, but not in the EU advanced countries, where technological progress is captured by Internet penetration. We can link this to the dynamics of mobile cellular subscriptions, which was much more important for the CEE countries relative to the EU advanced countries.

While education appears as cash usage determinant in both groups of countries, its effect is stronger in the CEE countries. In the euro area the cash usage is homogeneous among different educational categories (Esselink and Hernández 2017), relative to the finding of Végsö et al. (2018) who report a significant concentration of cash usage in the case of individuals with a lower educational attainment.

We do not find any robust evidence for the age dependency ratio for EU advanced countries. This might be due to changing behavioural patterns during the studied period (see, for example, van der Cruijsen and Plooij 2018 for a detailed analysis of shifting preferences in various sociodemographic groups). We fail to find a significant relationship between the share of self-employed and our cash measure, thus our empirical results do not support the belief that self-employment encourages usage of cash. Moreover, corruption perception reveals no significant impact on cash usage. This could be explained by the nature of our cash measure that relies on official withdrawal transactions and do not include secondary use of cash.

We fail to find a significant relationship between cash usage and cost components and cash payment limits. This result should be interpreted with caution due to limitations of our study. Our measure of cash usage includes both transactional and hoarding motive, whereas the cost measures are focused mainly on transactional reasoning (with the exception of opportnity withdrawal cost). 


\subsection{Summary}

In the CEE countries, the main cash usage determinants are ATM/POS ratio, GDP per capita, mobile users, consumer confidence, educaton, age dependency ratio, with ATM/POS and GDP exhibiting the strongest economic effect.

In the EU advanced countries cash usage is determined by ATM/POS ratio, GDP per capita, Internet users, Gini and 2008-2009 financial crisis.

Overall, we find that the payment system characteristics analyzed via the relative number of ATM and POS terminals play an important role in determining cash usage in both $\mathrm{CEE}$ and EU advanced countries. However, other types of factors (technological, socioeconomic and socio-cultural) also play a role, therefore considering only advancements in payment system characteristics may not provide a full picture to understand cash usage.

The summary of our results can also be found in Table 7 .

\section{Conclusions}

The last two decades were characterized by an increased development of innovations and reforms in payment systems designed to boost the use of electronic payment instruments. In this context, the question of cash substitution by alternative means of payment was particularly important for central banks and other participants in the payment cycle. This paper investigates the determinants of cash usage in a sample of 19 European countries. Projecting the individual drivers of cash usage at an aggregate level, we have been able to compare the dynamics of cash according to the characteristics of different countries in terms of technological, socioeconomic, and socio-cultural factors. We have then been able to compare the determinants of cash usage for EU advanced countries and Central and Eastern European countries highlighting significant and counterintuitive evidence.

We report the existence of both common and diverging determinants of cash usage in two groups of countries. We find that payment systems characteristics, in particular the number of ATMs relative to POS terminals is an important factor positively related to cash usage in the $\mathrm{CEE}$ and EU advanced countries. The socio-cultural factor education attainment is negatively related to cash usage in CEE countries. Technological factors reveal different results. In CEE countries cash usage is negatively correlated with the number of mobile users. In the case of EU advanced countries Internet users are positively related with cash usage, indicating that Internet proliferation stimulates transactions in general and propels the use of various payment media. In terms of income, real GDP per capita and the Gini coefficient show a negative impact on cash usage for EU advanced countries. However, in CEE countries cash usage is positively correlated with GDP, perceived level of uncertainty and age dependency ratio. We identify no robust relationship between cash usage and negative interest rate, cash payment limits, relative time cost and relative safety perceptions of cards compared to cash, the percentage of self-employed in total active population and corruption.

Comparing countries according to their characteristics appears to be an interesting exercise. Cultural aspects deserve to be investigated in further detail to understand 
differences. Additionally, many studies are based on advanced countries, while CEE countries exhibit some typical interesting trends that reveal money demands more clearly.

Never-ending technological upheavals will continue shaping the payment industry, so future research can focus on the crowding-out effect of innovative payment means based, for example, on blockchain. We have omitted cryptocurrency in our paper for several reasons. First, there is no consensus on whether instruments such as bitcoin should be considered as currency, because some of the characteristics of money (e.g. store of value) are violated, which is why central banks use the term "cryptoassets" to describe this class instead. Second, this is still a nascent phenomenon, and some inherent issues, such as reproduction at a negligible cost, should be solved before these instruments can realize their potential on a wider scale. Meanwhile, central banks are now reflecting on how to pave the way for a digital currency, such as CBDC (central bank digital currency), that would have the features of cash, but would be less costly to produce. The acceptance of such a method of payment, and its ability to substitute for traditional cash, looks like a promising avenue for further research. Finally, another area of future research can focus on the cash usage following the Covid-19 sanitary crisis. Since the crisis outbreak, the demand for cash for transactional motives has declined, yet the demand for cash for hoarding motives has increased (Rogoff and Scazzero 2021). Therefore, the Covid-19 pandemic raises many issues about cash usage, in particular, whether the changes in current habits induced by the sanitary crisis (Caswell et al. 2020) will be permanent or whether the determinants of cash usage that we describe will prevail.

\section{Appendix}

Table 2 List of countries retained for the analysis

\begin{tabular}{ll}
\hline CEE Countries & EU advanced countries \\
\hline Bulgaria & Belgium \\
Czech Republic & Finland \\
Estonia & France \\
Hungary & Germany \\
Latvia & Ireland \\
Lithuania & Italy \\
Roamnia & Netherlands \\
Slovakia & Portugal \\
Slovenia & Spain \\
& UK \\
\hline
\end{tabular}


Table 3 Descriptive statistics

\begin{tabular}{|c|c|c|c|c|c|}
\hline & Mean & Sd. & Min & Max & Obs \\
\hline \multicolumn{6}{|l|}{ Panel A: CEE countries } \\
\hline Cash usage & 1.652 & 0.319 & 1.119 & 2.382 & 121 \\
\hline ATM/POS & 0.072 & 0.053 & 0.022 & 0.358 & 122 \\
\hline Relative opportunity time cost & 0.023 & 0.032 & 0.0017 & 0.195 & 102 \\
\hline Relative safety perceptions & 0.035 & 0.023 & 0.006 & 0.130 & 126 \\
\hline $\log$ GDP & 9.285 & 0.379 & 8.286 & 9.909 & 126 \\
\hline Negative interest rate & 0.528 & 0.501 & 0 & 1 & 106 \\
\hline Internet users & 57.127 & 18.334 & 8.9 & 88.412 & 126 \\
\hline Mobile users & 113.617 & 25.809 & 31.709 & 165.056 & 126 \\
\hline Cash limits & 0.026 & 0.047 & 0 & 0.129 & 126 \\
\hline Gini & 30.346 & 5.028 & 22 & 38.9 & 116 \\
\hline Consumer confidence & -20.553 & 13.963 & -59.333 & 9.892 & 126 \\
\hline Self-employed & 0.113 & 0.031 & 0.067 & 0.181 & 126 \\
\hline Corruption perceptions & 4.967 & 0.97 & 2.8 & 7 & 126 \\
\hline Age dependency ratio & 77.264 & 5.096 & 66.4 & 86.8 & 126 \\
\hline Education & 19.719 & 6.547 & 7.9 & 34.1 & 126 \\
\hline \multicolumn{6}{|l|}{ Panel B: EU advanced countries } \\
\hline Cash usage & 1.671 & 0.426 & 0.706 & 2.733 & 140 \\
\hline ATM/POS & 0.056 & 0.032 & 0.011 & 0.134 & 138 \\
\hline Relative opportunity time cost & 0.470 & 1.039 & 0.002 & 9.344 & 132 \\
\hline Relative safety perceptions & 0.035 & 0.027 & 0.003 & 0.152 & 138 \\
\hline $\log$ GDP & 10.384 & 0.276 & 9.725 & 10.95 & 140 \\
\hline Negative interest rate & 0.466 & 0.501 & 0 & 1 & 133 \\
\hline Internet users & 69.036 & 17.487 & 29.04 & 94.776 & 140 \\
\hline Mobile users & 113.074 & 19.394 & 68.897 & 172.322 & 140 \\
\hline Cash limits & 0.032 & 0.054 & 0 & 0.145 & 140 \\
\hline Gini & 30.066 & 3.275 & 25.1 & 38.1 & 134 \\
\hline Consumer confidence & -11.542 & 14.336 & -47.892 & 19.508 & 140 \\
\hline Self-employed & 0.13 & 0.033 & 0.088 & 0.227 & 140 \\
\hline Corruption perceptions & 7.311 & 1.309 & 3.9 & 9.700 & 140 \\
\hline Age dependency ratio & 82.748 & 5.764 & 70.3 & 98 & 140 \\
\hline Education & 25.701 & 7.248 & 9.1 & 38.4 & 140 \\
\hline
\end{tabular}

This table reports descriptive statistics for the variables used in our analysis. Panel A refers to CEE countries (Bulgaria, Czech Republic, Estonia, Hungary, Latvia, Lithuania, Romania, Slovakia, Slovenia). Panel B focuses on EU advanced countries (Belgium, Finland, France, Germany, Ireland, Italy, Netherlands, Portugal, Spain, UK). Variables definitions and data sources are provided in Table 6 
Table 4 Determinants of cash usage: CEE countries

\begin{tabular}{|c|c|c|c|c|}
\hline & \multicolumn{2}{|l|}{ Fixed effects } & \multicolumn{2}{|l|}{ 2SLS } \\
\hline & (1) & (2) & (3) & (4) \\
\hline \multirow[t]{2}{*}{ ATM/POS } & $7.853^{* * *}$ & & $11.24 * * *$ & \\
\hline & $(4.99)$ & & $(6.60)$ & \\
\hline \multirow[t]{2}{*}{ Relative opportunity time cost } & -0.233 & -0.0985 & 1.963 & 12.37 \\
\hline & $(-0.45)$ & $(-0.07)$ & $(0.86)$ & $(0.95)$ \\
\hline \multirow[t]{2}{*}{ Relative safety perceptions } & -0.283 & -0.719 & 0.413 & 2.359 \\
\hline & $(-0.36)$ & $(-0.65)$ & $(0.42)$ & $(0.63)$ \\
\hline \multirow[t]{2}{*}{$\log$ GDP } & $2.049 * * *$ & $1.467 * *$ & $2.222 * * *$ & $1.484 * *$ \\
\hline & $(6.78)$ & $(3.12)$ & $(5.86)$ & $(2.32)$ \\
\hline \multirow[t]{2}{*}{ Mobile users } & $-0.00716^{* * *}$ & & $-0.00380^{*}$ & \\
\hline & $(-5.69)$ & & $(-1.87)$ & \\
\hline \multirow[t]{2}{*}{ Negative interest rate } & -0.0210 & & -0.0419 & \\
\hline & $(-0.70)$ & & $(-1.10)$ & \\
\hline \multirow[t]{2}{*}{ Cash limits } & 0.0441 & & 0.152 & \\
\hline & $(0.14)$ & & $(0.59)$ & \\
\hline \multirow[t]{2}{*}{ Gini } & -0.00932 & 0.0104 & -0.00562 & $0.0220 * *$ \\
\hline & $(-1.11)$ & $(1.80)$ & $(-0.75)$ & $(2.39)$ \\
\hline \multirow[t]{2}{*}{ Consumer confidence } & $-0.00452^{* *}$ & $-0.00414 * *$ & $-0.00555^{* * *}$ & $-0.00760 *$ \\
\hline & $(-3.23)$ & $(-2.66)$ & $(-4.55)$ & $(-1.92)$ \\
\hline \multirow[t]{2}{*}{ Crisis 2008-2009 } & -0.0129 & -0.0191 & -0.0333 & -0.0301 \\
\hline & $(-0.42)$ & $(-0.55)$ & $(-0.93)$ & $(-0.40)$ \\
\hline \multirow[t]{2}{*}{ Crisis 2011-2012 } & -0.00958 & -0.0191 & 0.00292 & 0.0616 \\
\hline & $(-0.30)$ & $(-0.54)$ & $(0.10)$ & $(0.76)$ \\
\hline \multirow[t]{2}{*}{ Self-employed } & 1.403 & 3.810 & -1.521 & -6.357 \\
\hline & $(0.99)$ & $(1.14)$ & $(-0.99)$ & $(-0.71)$ \\
\hline \multirow[t]{2}{*}{ Corruption perceptions } & -0.0654 & -0.0246 & -0.0886 & -0.169 \\
\hline & $(-1.53)$ & $(-0.61)$ & $(-1.60)$ & $(-1.28)$ \\
\hline \multirow[t]{2}{*}{ Age dependency ratio } & $0.0216^{* *}$ & 0.0234 & $0.0185^{* * *}$ & 0.0190 \\
\hline & $(2.85)$ & $(1.51)$ & $(2.67)$ & $(1.63)$ \\
\hline \multirow[t]{2}{*}{ Education } & $-0.0515^{* * *}$ & $-0.0817 * * *$ & $-0.0626 * * *$ & $-0.143 * *$ \\
\hline & $(-8.17)$ & $(-5.92)$ & $(-3.87)$ & $(-2.14)$ \\
\hline \multirow[t]{2}{*}{ Constant } & $-17.35 * * *$ & $-12.86^{* *}$ & & \\
\hline & $(-6.08)$ & $(-2.97)$ & & \\
\hline Observations & 95 & 99 & 93 & 98 \\
\hline$R^{2}$ & 0.846 & 0.684 & & \\
\hline Endogeneity test & & & 5.564 & 2.743 \\
\hline ( $p$-value) & & & $(0.061)$ & $(0.097)$ \\
\hline Sargan-Hansen test & & & 0.629 & 0.038 \\
\hline ( $p$-value $)$ & & & $(0.730)$ & $(0.845)$ \\
\hline
\end{tabular}

$t$-statistics/Z-statistics in parentheses

$* p<0.1, * * p<0.05$, *** $p<0.01$

Endogeneity test rejects the null hypothesis of the possibility to treat endogenous regressors as exogenous for all models. Also, for all models, the Sargan-Hansen overidentification test fails to reject the joint null hypothesis that the instruments are valid instruments, i.e. uncorrelated with the error term, and that the excluded instruments are correctly excluded from the estimated equation 
Table 5 Determinants of cash usage: EU advanced

\begin{tabular}{|c|c|c|c|c|}
\hline & \multicolumn{2}{|l|}{ Fixed effects } & \multicolumn{2}{|l|}{ 2SLS } \\
\hline & (1) & (2) & (3) & (4) \\
\hline ATM/POS & $\begin{array}{l}4.952 * \\
(2.17)\end{array}$ & & $\begin{array}{l}8.293^{*} \\
(1.89)\end{array}$ & \\
\hline Relative opportunity time cost & $\begin{array}{l}-0.0161 \\
(-1.07)\end{array}$ & $\begin{array}{l}-0.0145 \\
(-0.67)\end{array}$ & $\begin{array}{l}0.235 \\
(0.78)\end{array}$ & $\begin{array}{l}0.266 \\
(0.84)\end{array}$ \\
\hline Relative safety perceptions & $\begin{array}{l}-4.051 * * \\
(-2.45)\end{array}$ & $\begin{array}{l}-4.682 * * \\
(-2.62)\end{array}$ & $\begin{array}{l}-1.169 \\
(-0.36)\end{array}$ & $\begin{array}{l}-1.247 \\
(-0.52)\end{array}$ \\
\hline $\log$ GDP & $\begin{array}{l}-0.278 \\
(-0.45)\end{array}$ & $\begin{array}{l}0.0452 \\
(0.08)\end{array}$ & $\begin{array}{l}-2.303^{*} \\
(-1.83)\end{array}$ & $\begin{array}{l}-2.261^{* *} \\
(-2.28)\end{array}$ \\
\hline Internet users & $\begin{array}{l}0.0119^{* * * *} \\
(3.36)\end{array}$ & & $\begin{array}{l}0.0121^{* *} \\
(2.35)\end{array}$ & \\
\hline Negative interest rate & $\begin{array}{l}0.00640 \\
(0.23)\end{array}$ & & $\begin{array}{l}-0.0841 \\
(-1.58)\end{array}$ & \\
\hline Cash limits & $\begin{array}{l}-0.199 \\
(-0.35)\end{array}$ & & $\begin{array}{l}-0.369 \\
(-0.49)\end{array}$ & \\
\hline Gini & $\begin{array}{l}-0.0453^{*} \\
(-2.08)\end{array}$ & $\begin{array}{l}-0.0190 \\
(-0.64)\end{array}$ & $\begin{array}{l}-0.0878^{* * *} \\
(-3.41)\end{array}$ & $\begin{array}{l}-0.0594^{* *} \\
(-2.42)\end{array}$ \\
\hline Consumer confidence & $\begin{array}{l}0.000567 \\
(0.25)\end{array}$ & $\begin{array}{l}-0.00133 \\
(-0.54)\end{array}$ & $\begin{array}{l}0.00951 * \\
(1.83)\end{array}$ & $\begin{array}{l}0.00791 * \\
(1.79)\end{array}$ \\
\hline Crisis 2008-2009 & $\begin{array}{l}0.0576 \\
(1.36)\end{array}$ & $\begin{array}{l}0.0742 * \\
(2.12)\end{array}$ & $\begin{array}{l}0.175^{*} \\
(1.69)\end{array}$ & $\begin{array}{l}0.217^{* *} \\
(2.48)\end{array}$ \\
\hline Crisis 2011-2012 & $\begin{array}{l}-0.0303 \\
(-1.27)\end{array}$ & $\begin{array}{l}-0.0143 \\
(-0.51)\end{array}$ & $\begin{array}{l}0.201 \\
(1.33)\end{array}$ & $\begin{array}{l}0.171 \\
(1.37)\end{array}$ \\
\hline Self-employed & $\begin{array}{l}-0.253 \\
(-0.08)\end{array}$ & $\begin{array}{l}-0.351 \\
(-0.12)\end{array}$ & $\begin{array}{l}4.583 \\
(1.21)\end{array}$ & $\begin{array}{l}4.234 \\
(1.10)\end{array}$ \\
\hline Corruption perceptions index & $\begin{array}{l}0.122 \\
(1.79)\end{array}$ & $\begin{array}{l}0.0939 \\
(0.91)\end{array}$ & $\begin{array}{l}0.00786 \\
(0.10)\end{array}$ & $\begin{array}{l}-0.0213 \\
(-0.29)\end{array}$ \\
\hline Age dependency ratio & $\begin{array}{l}-0.00000332 \\
(-0.00)\end{array}$ & $\begin{array}{l}0.000163 \\
(0.01)\end{array}$ & $\begin{array}{l}-0.0212 \\
(-0.76)\end{array}$ & $\begin{array}{l}-0.0296 \\
(-1.14)\end{array}$ \\
\hline Education & $\begin{array}{l}-0.0601 * * * \\
(-3.47)\end{array}$ & $\begin{array}{l}-0.0249 \\
(-1.58)\end{array}$ & $\begin{array}{l}-0.0541^{* * *} \\
(-3.09)\end{array}$ & $\begin{array}{l}-0.0199 \\
(-0.98)\end{array}$ \\
\hline Constant & $\begin{array}{l}5.662 \\
(0.87)\end{array}$ & $\begin{array}{l}1.890 \\
(0.29)\end{array}$ & & \\
\hline Observations & 124 & 126 & 117 & 120 \\
\hline$R^{2}$ & 0.638 & 0.554 & & \\
\hline $\begin{array}{l}\text { Endogeneity test } \\
(p \text {-value })\end{array}$ & & & $\begin{array}{l}7.058 \\
(0.029)\end{array}$ & $\begin{array}{l}4.103 \\
(0.042)\end{array}$ \\
\hline $\begin{array}{l}\text { Sargan-Hansen test } \\
\text { (p-value) }\end{array}$ & & & $\begin{array}{l}0.158 \\
(0.690)\end{array}$ & $\begin{array}{l}0.448 \\
(0.503)\end{array}$ \\
\hline
\end{tabular}

$t$-statistics/Z-statistics in parentheses

$* p<0.1, * * p<0.05$, *** $p<0.01$

Endogeneity test rejects the null hypothesis of the possibility to treat endogenous regressors as exogenous for all models. Also, for all models, the Sargan-Hansen overidentification test fails to reject the joint null hypothesis that the instruments are valid instruments, i.e. uncorrelated with the error term, and that the excluded instruments are correctly excluded from the estimated equation 


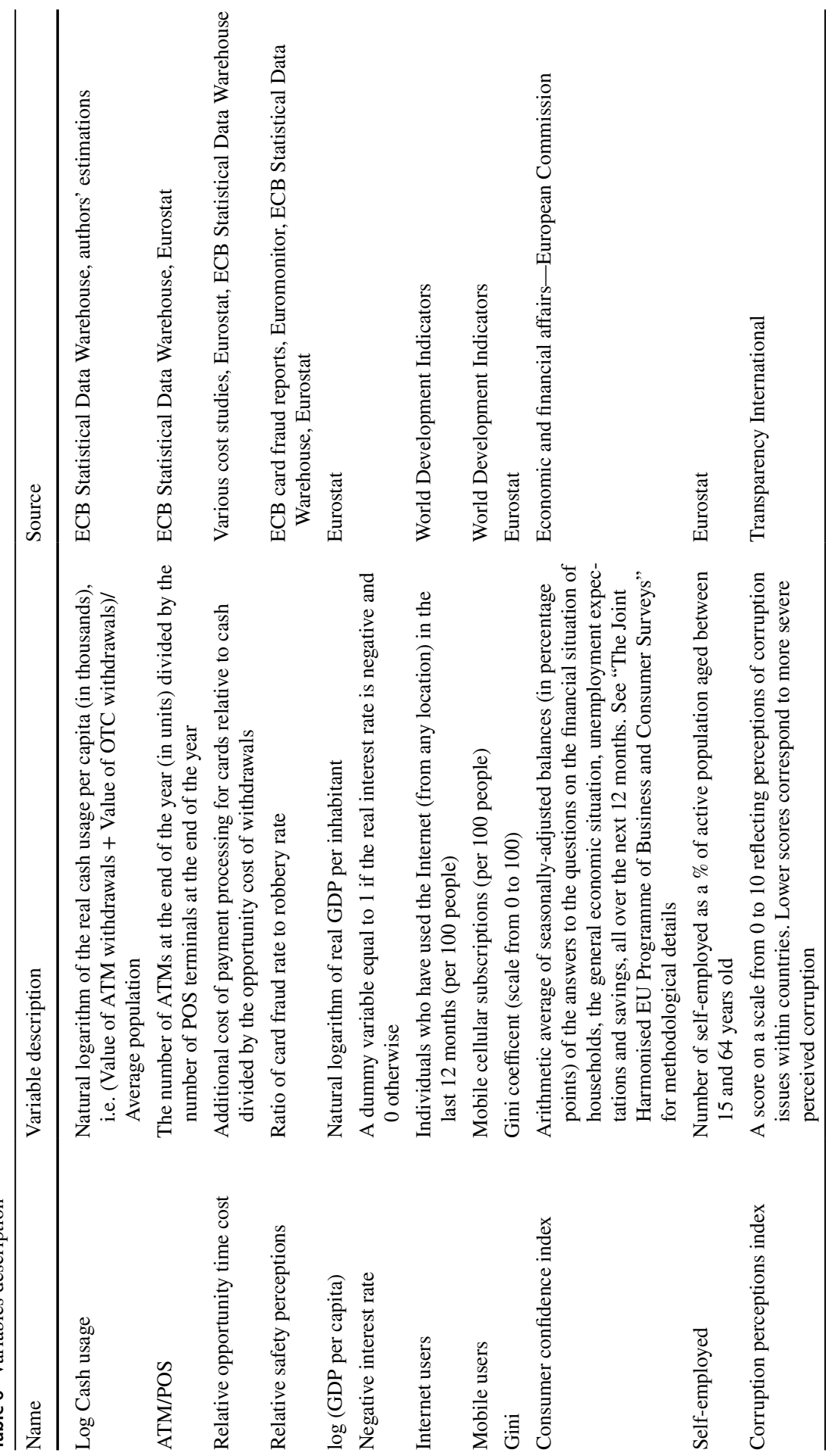




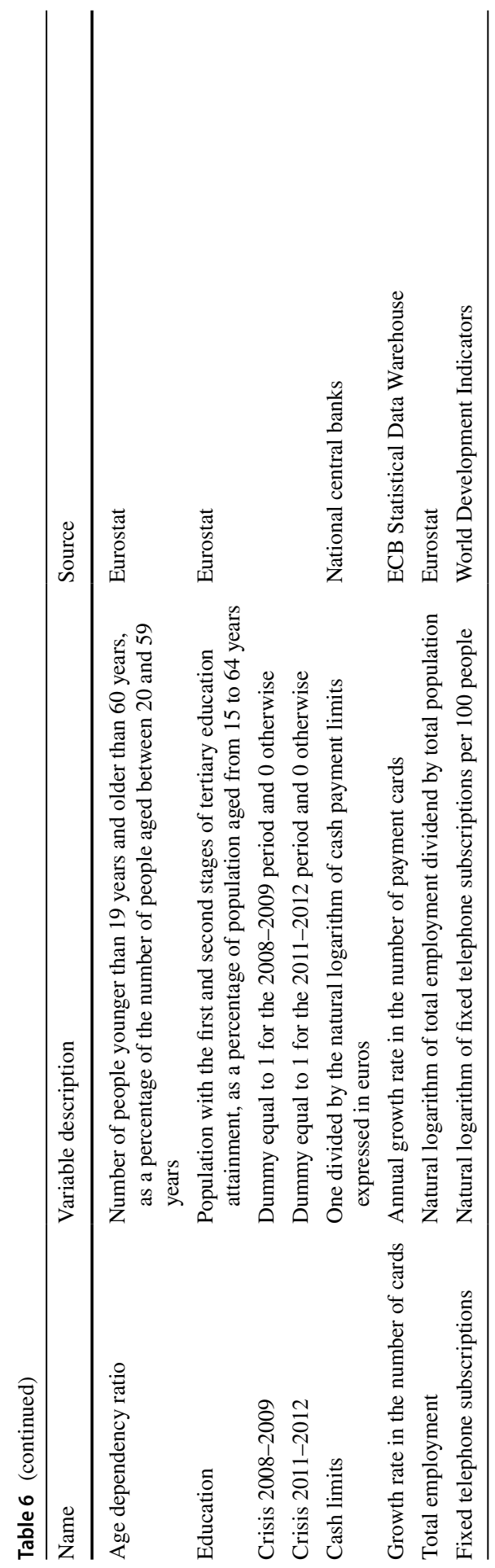


Table 7 Summary of results

\section{CEE Countries EU advanced countries}

Common factors

$\begin{array}{lcc}\text { ATM/POS } & + \text { (strong) } & + \text { (weak) } \\ \text { Education } & - \text { (strong) } & - \text { (marginally signifi- } \\ & & \text { cant) }\end{array}$

Region-specific factors

$\begin{array}{lll}\text { GDP } & + \text { (strong }) & - \text { (weak) } \\ \text { Consumer confidence } & - \text { (strong }) & + \text { (weak) } \\ \text { Age dependency ratio } & + \text { (moderate) } & \\ \text { Mobile users } & - \text { (strong) } & \\ \text { Internet user } & & + \text { (moderate }) \\ \text { Gini } & - \text { (strong) } \\ \text { Crisis 2008-2009 } & + \text { (weak) }\end{array}$

Acknowledgments We would like to thank the editor and the two anonymous reviewers for their helpful comments and suggestions as well as the participants of the 18th INFER Annual Conference and INSEEC U. Research Symposium for interesting discussions on an earlier version of this article.

\section{References}

Abele, H. A., \& Schaefer, G. K. (2016). The cost of cash and debit cards in Austria. Journal of Financial Market Infrastructures, 4(4), 1-16.

Albulescu, C. T., Pépin, D., \& Miller, S. M. (2019). The micro-foundations of an open economy money demand: An application to central and eastern European countries. Journal of Macroeconomics, $60(\mathrm{C}), 33-45$.

Alvarez, F., \& Lippi, F. (2009). Financial innovation and the transactions demand for cash. Econometrica, 77(2), 363-402.

Amromin, G., \& Chakravorti, S. (2009). Whither loose change? The diminishing demand for smalldenomination currency. Journal of Money, Credit and Banking, 41(2-3), 315-335.

Arango-Arango, C., \& Suárez-Ariza, N. F. (2019). Digital Payments Adoption and the Demand for Cash: New International Evidence. Borradores de Economia 1074 (4), Banco de la Republica de Colombia.

Arango, C. A., Bouhdaoui, Y., Bounie, D., Eschelbach, M., \& Hernández, L. (2018). Cash remains topof-wallet! International evidence from payment diaries. Economic Modelling, 69, 38-48.

Ashworth, J., \& Goodhart, C. A. E. (2020). The surprising recovery of currency usage. International Journal of Central Banking, 16(3), 239-277.

Attanasio, O. P., Guiso, L., \& Jappelli, T. (2002). The demand for money, financial innovation, and the welfare cost of inflation: An analysis with household data. Journal of Political Economy, 110(2), 317-351.

Bagnall, J., Bounie, D., Huynh, K. P., Kosse, A., Schmidt, T., Schuh, S., \& Stix, H. (2016). Consumer cash usage: A cross-country comparison with payment diary survey data. International Journal of Central Banking, 12(4), 1-61.

Banque Nationale de Belgique (2005). Coûts, avantages et inconvénients des différents moyens de paiement.

Bartzsch, N., Rösl, G., \& Seitz, F. (2013). Currency movements within and outside a currency union: The case of Germany and the euro area. The Quarterly Review of Economics and Finance, 53(4), 393-401.

Bech, M. L., Faruqui, U., Ougaard, F., \& Picillo, C. (March 2018). Payments are A-Changin' But Cash Still Rules. BIS Quarterly Review. https://ssrn.com/abstract=3139217. 
Borzekowski, R., Kiser, E., \& Ahmed, S. (2008). Consumers' use of debit cards: Patterns, preferences, and price response. Journal of Money, Credit and Banking, 40, 149-172.

Bouhdaoui, Y., \& Bounie, D. (2012). Modeling the share of cash payments in the economy: An application to France. International Journal of Central Banking, 8(4), 175-195.

Bounie, D., François, A., \& Waelbroeck, P. (2016). Debit card and demand for cash. Journal of Banking \& Finance, 73, 55-66.

Brits, H., \& Winder, C. (2005). Payments are no free lunch. DNB Occasional Studies, 3(2).

Buelens, C., \& Tirpák, M. (2017). Reading the footprints: how foreign investors shape countries' participation in global value chains. ECB Working Paper Series 2060.

Cabinakova, J., Knumann, F., \& Horst, F. (2017). The costs of cash payments in the retail sector: Study to determine and evaluate the costs arising from cash payments in the retail sector. Deutsche Bundesbank.

Cameron, A., \& Miller, D. (2015). Practitioner's guide to cluster-robust inference. Journal of Human Resources, 50(2), 317-372.

Carbo-Valverde, S., \& Rodriguez-Fernandez, F. (2019). An international approach to the cost of payment instruments: The case of cash. Available at: http://full-report-cost-of-cash-may-2019-1.pdf (wordp ress.com)

Caswell, E., Smith, M., Learmonth, D., \& Pearce, G. (2020). Cash in the Time of Covid. Bank of England. http://www.bankofengland.co.uk/quarterly-bulletin/2020/2020-q4/cash-in-the-time-of-covid.

Dachs, B. (2018). The impact of new technologies on the labour market and the social economy. European Parliamentary Research Service - Study.

Danmarks Nationalbank (2012). Costs of payments in Denmark, Danmarks Nationalbank.

Drehmann, M., Goodhart, C. A. E., \& Kruger, M. (2002). The challenges facing currency usage: Will the traditional transactions medium be able to resist competition from the new technologies? Economic Policy, 17(34), 195-227.

Esselink, H., \& Hernández, L. (2017). The use of cash by households in the euro area. ECB Occasional Paper No. 201.

Evans, D. S., Webster, K., Colgan, G. K., \& Murray, S. R. (June 2013). Paying with Cash: A MultiCountry Analysis of the Past and Future of the Use of Cash for Payments by Consumers. Available at SSRN: http://ssrn.com/abstract=2273192.

Goczek, L., \& Witkowski, B. (2016). Determinants of card payments. Applied Economics, 48(16), $1530-1543$.

Goodhart, C., \& Ashworth, J. (2014). Trying to glimpse the 'grey economy'. Available at: https://voxeu. org/article/trying-glimpse-grey-economy.

Górka, J. (2012). Payment Behaviour in Poland - The Benefits and Costs of Cash, Cards and Other NonCash Payment Instruments. In book: The usage, costs and benefits of cash: Theory and evidence from macro and micro data Edition 1, Chapter 9, 448-472.

Guariglia, A., \& Loke, Y. (2004). What determines the value and volume of noncash transactions? Evidence from a panel of European and North American countries. Applied Economics, 36, 291-303.

Hazra, D. (2017). Monetary policy and alternative means of payment. The Quarterly Review of Economics and Finance, 65, 378-387.

Hernandez, L., Jonker, N., \& Kosse, A. (2017). Cash versus debit card: The role of budget control. Journal of Consumer Affairs, 51(1), 91-112.

Humphrey, D. B. (2010). Retail payments: New contributions, empirical results, and unanswered questions. Journal of Banking \& Finance, 34, 1729-1737.

Humphrey, D., Pulley, L., \& Vesala, J. M. (1996). Cash, paper, and electronic payments: A cross-country analysis. Journal of Money, Credit and Banking, 28(4), 914-939.

Ilyés, T., \& Varga, L. (2015). Show me how you pay and I will tell you who you are-Socio-demographic determinants of payment habits. Financial and Economic Review, 14(2), 25-61.

Jobst, C., \& Stix, H. (2017). Doomed to disappear? CEPR Discussion Paper Series: The surprising return of cash across time and across countries.

Jonker, N. (2007). Payment instruments as perceived by consumers-Results from a household survey. De Economist, 155(3), 271-303.

Jonker, N. (2013). Social costs of POS payments in the Netherlands 2002-2012: Efficiency gains from increased debit card usage. DNB Occasional Studies, 11(2).

Jonker, N., Kosse, A., \& Hernández, L. (2012). Cash usage in the Netherlands: How much, where, when, who and whenever one wants? DNB Occasional Studies,10(2). 
Jonker, N., Plooij, M., \& Verburg, J. (2017). Did a public campaign influence debit card usage ? Evidence from the Netherlands. Journal of Financial Services Research, 52(1-2), 89-121.

Klee, E. (2008). How people pay: Evidence from grocery store data. Journal of Monetary Economics, $55(3), 526-41$.

Kosse, A. (2013). The safety of cash and debit cards: A study on the perception and behavior of Dutch consumers. International Journal of Central Banking, 9(4), 77-98.

Kosse, A., \& Jansen, D.-J. (2013). Choosing how to pay: The influence of foreign backgrounds. Journal of Banking \& Finance, 37(3), 989-998.

Krüger, M., \& Seitz, S. (2014). Costs and benefits of cash and cashless payment instruments-Overview and initial estimates. Deutsche Bundesbank.

Lalouette, L., \& Esselink, H. (2018). Trends and developments in the use of euro cash over the past ten years. Economic Bulletin Articles 6, European Central Bank.

Lippi, F., \& Secchi, A. (2009). Technological change and the households' demand for currency. Journal of Monetary Economics, 56(2), 222-230.

Markose, S. M., \& Loke, Y. J. (2003). Network effects on cash-card substitution in transactions and low interest rate regimes. The Economic Journal, 113(487), 456-476.

Martikainen, E., Schmiedel, H., \& Takalo, T. (2015). Convergence of European retail payments. Journal of Banking \& Finance, 50, 81-91.

Petersen, M. (2009). Estimating standard errors in finance panel data sets: Comparing approaches. Review of Financial Studies, 22, 435-480.

Polasik, M., Górka, J., Wilczewski, G., Kunkowski, J., Przenajkowska, K., \& Tetkowska, N. (2010). Time efficiency of Point-of-Sale payment methods: Empirical results for cash, cards and mobile payments. Journal of Internet Banking and Commerce, 15(3), 1-11.

Rogoff, K., \& Scazzero, J. (2021). COVID Cash. CMFA Working Paper 002.

Schaffer, M. E. (2010). xtivreg2: Stata module to perform extended IV/2SLS, GMM and AC/HAC, LIML and k-class regression for panel data models. http://ideas.repec.org/c/boc/bocode/s456501.html

Schmiedel, H., Kostova, G., \& Ruttenberg, W. (2012). The Social and Private Costs of Retail Payment Instruments: A European Perspective. ECB Occasional Paper 137.

Scholnick, B., Massoud, N., Saunders, A., Carbo-Valverde, S., \& Rodríguez-Fernández, F. (2008). The economics of credit cards, debit cards and ATMs: A survey and some new evidence. Journal of Banking \& Finance, 32(8), 1468-1483.

Scholten, B. (2017). Decline management: the case of cash. Policy response in the Netherlands and the Nordic countries. International Cash Conference 2017.

Segendorf, B. L., \& Jansson, T. (2012). The Cost of Consumer Payments in Sweden. Sveriges Riksbank Research Paper Series 262.

Seitz, F., \& Krueger, M. (2017). The blessing of cash. International Cash Conference 2017.

Shujah-ur-Rahman, S., Chen, S., Saud, S., Saleem, N., \& Bari, M. W. (2019). Nexus between financial development, energy consumption, income level, and ecological footprint in CEE countries: Do human capital and biocapacity matter? Environmental Science and Pollution Research, 26(31), 31856-31872.

Silva, V. G., Ramalho, E. A., \& Vieira, C. R. (2017). The use of cheques in the European Union: A crosscountry analysis. Open Economic Review, 28(6), 581-602.

Snellman, J. S., Vesala, J. M., \& Humphrey, D. B. (2001). Substitution of noncash payment instruments for cash in Europe. Journal of Financial Services Research, 19(2), 131-145.

Snellman, H., \& Viren, M. (2009). ATM networks and cash usage. Applied Financial Economics, 19, $841-851$.

Srouji, J. (2020). Digital payments, the cashless economy, and financial inclusion in the United Arab emirates: Why is everyone still transacting in cash? Journal of Risk and Financial Management, 13(11), 1-10.

Świecka, B., \& Grima, S. (2019). Factors affecting the consumers' choice of payment instrument in Poland. European Research Studies Journal, 22(4), 179-198.

Takala, K., \& Viren, M. (2012). Estimating cash usage in the euro area. https://www.bundesbank.de/ Redaktion/EN/Downloads/Tasks/Cash_management/Conferences/2012_02_27_eltville_05_takala_ paper.pdf?_blob=publicationFile14.

Turján, A., Divéki, E., Keszy-Harmath, E., Kóczán, G., \& Takács, K. (2011). Nothing is free: A survey of the social cost of the main payment instruments in Hungary. MNB Occasional Papers 93. 
van der Cruijsen, C., Hernandez, L., \& Jonker, N. (2017). In love with the debit card but still married to cash. Applied Economics, 49(30), 2989-3004.

van der Cruijsen, C., \& van der Horst, F. (2019). Cash or card? Unravelling the role of socio-psychological factors. De Economist, 167(2), 145-175.

van der Cruijsen, C., \& Plooij, M. (2018). Drivers of payment patters at the point of sale: Stable or not? Contemporary Economic Policy, 36(2), 363-380.

Végsö, T. Á., \& B. I., Bódi-Scubert, A. . (2018). Cash or card? An explorative analysis of consumers' payment behaviour in hungary. Public Finance Quarterly State Audit Office of Hungary, 63(4), $448-472$.

von Kalckreuth, U., Schmidt, T., \& Stix, H. (2011). Using Cash to Monitor Liquidity - Implications for Payments, Currency Demand and Withdrawal Behaviour. European Central Bank Working Paper 1385 .

Publisher's Note Springer Nature remains neutral with regard to jurisdictional claims in published maps and institutional affiliations. 